\title{
Households' Willingness-to-Pay for Wastewater Treatment in Traditional Agro-Food Processing Villages, Nhue-Day River Basin, Vietnam: Case Study in Hanoi City
}

\author{
Tran Thi Thu Trang ${ }^{1 *}$, Roberto F. Rañola², Nguyen Van Song ${ }^{1}$ \\ ${ }^{1}$ Department of Resources and Environmental Economics, Faculty of Economics and Rural Development, Vietnam National \\ University of Agriculture, Hanoi, Vietnam \\ ${ }^{2}$ Department of Agricultural and Applied Economics, College of Economics and Management, University of the Philippines Los \\ Baños, Los Baños, Philippines \\ Email: ^tranthutrang1712@gmail.com
}

How to cite this paper: Trang, T.T.T., Rañola, R.F. and Song, N.V. (2018) Households' Willingness-to-Pay for Wastewater Treatment in Traditional Agro-Food Processing Villages, Nhue-Day River Basin, Vietnam: Case Study in Hanoi City. Journal of Environmental Protection, 9, 1021-1033. https://doi.org/10.4236/jep.2018.910063

Received: January 9, 2018

Accepted: September 2, 2018

Published: September 5, 2018

Copyright ( $\odot 2018$ by authors and Scientific Research Publishing Inc. This work is licensed under the Creative Commons Attribution International License (CC BY 4.0).

http://creativecommons.org/licenses/by/4.0/ (c) (i) Open Access

\begin{abstract}
Despite the number of studies focusing on the financial analysis of production activities, conducting on technical solutions, and improving water quality, no study has been conducted on the application of economic instruments that apply to water quality management in craft villages, and several studies of WTP also. This study aimed to estimate the households' willingness-to-pay for wastewater treatment in selected traditional agro-food processing villages in Nhue-Day River Basin, Vietnam. A pilot Choice Experiment (CE) technique in Choice Modelling (CM) approach was applied for this study with 267 selected agro-food processing households by using the conditional logit (CL) and random parameter logit (RPL) models. The results showed that total annual environmental fee for wastewater treatment from agro-food processing households is estimated as 1089 million VND (equal to US $\$ 47,868$ per year) for the total of 902 agro-food processing households in three research sites in Nhue-Day River Basin. This estimated budget for wastewater treatment accounted for $55.85 \%$ of total annual operation and maintenance costs only. In addition, the technology is improved to enable $90 \%$ of treated wastewater. Overall, the results of this study suggest the new wastewater treatment plant construction and improved wastewater collection system by increasing the investment in order to improve the water quality in Nhue-Day River Basin that brings about the reducing environmental degradation, biodiversity loss and human health risks.
\end{abstract}




\section{Keywords}

Wastewater Treatment, Willingness-to-Pay, Craft Villages, Choice

Experiment, Conditional Logit Model, Random Parameter Logit Model

\section{Introduction}

World-wide water utilization is severely affected by tremendous increase in population and industrialization [1]. These social phenomena result in increasingly wastewater volume and scarcity of water resource in many arid and semi-arid countries [2]. Moreover, sanitation networks and treatment plants are becoming overly saturated. As a consequence, polluted water is directly discharged into the natural environment [3]. Hence, rehabilitation and conservation of water resources are one of the main challenges in the 21 st century. The release of raw and improperly treated wastewater onto water courses has both short-term and long-term effects on the environment, loss of biodiversity in the aquatic ecosystem and human health [1].

Water quality degradation attributable to agricultural pollution entails costs concerning surface water quality [4] and water portability [5]. Over 12 million people were killed a year because of polluted water, water shortages, and unsanitary living conditions [6]. Programs and projects aiming to solve environmental pollution have not been implemented as efficiently as possible. Environmental quality and antipollution legislations are the most widely used interventions to control and reduce environmental pollution [7]. In most countries, environmental laws have been enacted by the government and enforced through its administrative structures [8]. However, the water pollution has not been improved.

Economic or market-based instruments such as pricing, pollution charges can support environmental protection and improvement by modifying the behavior of public and private polluters [9]. A basic principle of ecological economics used in environmental management is the "polluter pays" principle [9] [10] which emphasizes that anyone whose actions pollute or adversely affect the environment should pay the cost for remedial action. Ambec \& Ehlers [10] examined the distributional impact of the polluter-pays principle which requires that any agent compensates all other agents for the damages caused by his or her (pollution) emissions.

Nhue-Day river basin has more than two hundred villages are recognized as traditional craft villages by the Hanoi City People's Committee. The existing craft villages have been discharging a large volume of wastewater to Hanoi's rivers. The wastewater pollution level has been worsening yearly resulting in increasing risks to public health, especially to individuals who directly participate in the production activities, live within or near the exposed craft villages. The consequences of wastewater pollution are recorded by the high incidence of individuals with digestive disorder and eye infections (37\%), respiratory diseases 
(20\%), and dermatological diseases (31\%) [11].

The solutions from previous studies concentrating in financial and technical aspects have not brought effective outcomes for the improvement of water quality in the research site. Therefore, this study aimed to estimate how much the agro-food processing households are willing-to-pay to improve the water quality in the traditional agro-food processing craft villages in Hanoi city. It is very important to the policy makers because information about these matters is a critical element to develop the public wastewater treatment programs to address environmental pollution.

\section{Methodology}

This study applied Choice Experiment (CE) in Choice Modeling (CM) approach to estimate the Willingness-to-Pay (WTP) for sewage treatment.

\subsection{Site Selection}

Three traditional agro-food processing villages in Duong Lieu, Tan Hoa and Phu Do communes from three districts: Hoai Duc, Quoc Oai and Tu Liem of Hanoi City which belonged to the Nhue-Day River Basin were selected for this study. The criteria for selection are based on: 1) They are the villages which directly discharge wastewater to the Nhue-Day river basin without any treatment; 2) Typical agro-food processing craft villages in Hanoi City; 3) Quantity of wastewater in these villages are the largest among other areas; and 4) Only one wastewater treatment facility in the study sites has been installed and operated since October 2016.

\subsection{Sample Selection}

Due to the small number of households which produce the agricultural food product in Tan Hoa and Phu Do traditional craft villages, this study surveyed all the agro-food processing households in these villages. For Duong Lieu villages, this study choosed two hamlets. The first hamlet is inside the dike and second one is outside the dike. After that, this study surveyed the population size to collect the data.

From the total sample surveyed, 9 respondents provided protest responses and hence refused to answer to the Willingness-to-Pay question. Therefore, a total of 267 respondents fully completed the survey. The questionnaires were pre-tested by 30 selected households through face-to-face interview from the three communes to identify and confirm attributes, as well as to determine the plausibility of scenarios presented in the draft choice sets.

\subsection{Questionnaire Development}

Four attributes were chosen for choice experiment in this study including quantity of treated wastewater, restoration the ecosystem in Nhue-Day River Basin, improvement of wastewater collection system, and monthly additional environ- 
mental fee. Besides the attributes, the levels of each attribute were also determined. The final list of attributes and their assigned levels is presented in Table 1.

The respondents were shown the list of choice set cards (8 cards) and they selected the most favorite alternative in each card. An example of one choice set card is presented in Table 2 .

\section{Results and Discussions}

\subsection{Household Characteristics}

The information about the households' social, economic and demographic characteristics were also collected. A summary of households' characteristics from survey data are shown in Table 3.

Table 1. Attributes and attribute levels for wastewater treatment in the choice experiment.

\begin{tabular}{|c|c|c|c|}
\hline Attributes & Description & $\begin{array}{c}\text { Number of } \\
\text { classes }\end{array}$ & Level \\
\hline $\begin{array}{l}\text { Quantity } \\
\text { of treated } \\
\text { wastewater }\end{array}$ & $\begin{array}{l}\text { The capacity of the wastewater treatment plant } \\
\text { can be increased to treat the wastewater generated } \\
\text { with primary treatment. The respondents were } \\
\text { asked to consider the level of the total } \\
\text { wastewater they want to treat }\end{array}$ & 4 & $\begin{array}{l}40 \% \\
60 \% \\
70 \% \\
90 \%\end{array}$ \\
\hline $\begin{array}{l}\text { Restoration the } \\
\text { ecosystem in } \\
\text { Nhue-Day } \\
\text { River Basin }\end{array}$ & $\begin{array}{l}\text { There are no investments to restore or improve } \\
\text { the recreational activities provided by the } \\
\text { Nhue-Day River Basin, such as fishing } \\
\text { or swimming at present }\end{array}$ & 2 & $\begin{array}{l}\text { No } \\
\text { Yes }\end{array}$ \\
\hline $\begin{array}{l}\text { Improvement } \\
\text { of wastewater } \\
\text { collection system }\end{array}$ & $\begin{array}{l}\text { Improvement of wastewater collection system could } \\
\text { bring to higher flow rate of wastewater discharged to } \\
\text { the wastewater treatment plant and prevent the odor } \\
\text { or smell from long time wastewater accumulation so } \\
\text { as to minimize the health and environmental risks }\end{array}$ & 2 & $\begin{array}{l}\text { No } \\
\text { Yes }\end{array}$ \\
\hline $\begin{array}{l}\text { Monthly } \\
\text { additional } \\
\text { environmental fee }\end{array}$ & $\begin{array}{l}\text { A pilot Contingent Valuation survey will be used } \\
\text { to determine } 4 \text { levels of the payment vehicles in } \\
\text { thousands Vietnam Dong. These are the } \\
\text { additional amount of money levels } \\
\text { which households are WTP monthly }\end{array}$ & 4 & $\begin{array}{c}50 \\
100 \\
130 \\
200\end{array}$ \\
\hline
\end{tabular}

Table 2. Example of choice set card presented to households.

\begin{tabular}{|c|c|c|c|}
\hline Attributes & Alternative A & Alternative B & Status quo \\
\hline Quantity of treated wastewater & $60 \%$ & $70 \%$ & \\
\hline $\begin{array}{l}\text { Restoration the ecosystem } \\
\text { in Nhue-Day river basin }\end{array}$ & Yes & No & $\begin{array}{l}\text { Neither alternative } \mathrm{A} \\
\text { nor alternative B: }\end{array}$ \\
\hline $\begin{array}{c}\text { Improvement of } \\
\text { wastewater collection system }\end{array}$ & No & Yes & $\begin{array}{l}\text { I prefer to stay } \\
\text { with my current service }\end{array}$ \\
\hline Additional monthly fee & 50 & 130 & \\
\hline Your choice & & & \\
\hline
\end{tabular}


Table 3. Social, economic and demographic characteristics of the sampled households.

\begin{tabular}{ccc}
\hline Independent variables & Mean & Std. Err \\
\hline Decision maker & 0.70 & 0.028 \\
Gender of respondent & 0.73 & 0.027 \\
Age of respondent & 46.15 & 0.489 \\
Education of respondent & 8.064 & 0.131 \\
Experience of respondent & 16.64 & 0.465 \\
Agro-food processing household & 0.92 & 0.165 \\
Quantity of untreated wastewater & 107.94 & 7.17 \\
Children below 16 years old & 0.55 & 0.031 \\
Frequency of occurrence of sickness by family members & 2.99 & 0.148 \\
Awareness of wastewater treatment benefits & 0.648 & 0.029 \\
Access to credit facilities & 0.59 & 0.03 \\
Membership of craft village's association & 0.74 & 0.027 \\
Logarithm of average monthly household income & 1.391 & 0.020 \\
\hline
\end{tabular}

The results showed that most of respondents in agro-food processing craft villages in Hanoi City are male (73\%), older (about 46 years old), and decision makers of huosehold (70\%). Respondents in the survey are working in agro-food processing field (93\%) and are members in craft village's association (74\%). However, the respondents' educational level is about eight years; which means that they haven't completed the secondary school. In addition, the results showed that about $55 \%$ of households have at least one child below 16 years old in their family and have members who got sick three times within 6 months ago. Quantity of untreated wastewater from household was 107.94 cubic meters per month which came from domestics and agro-food processing activity. The results reported that monthly income of the survey households was high (about 25 million VND or 1099 US dollar). About 64.8\% of interviewees are aware of the benefits of wastewater treatment.

\subsection{Data Coding}

In the choice experiment, the dummy coding was used for ecosystem restoration and wastewater collection system improvement attributes where 1 denoted for "yes" response (i.e. investment in restoration of ecosystem or investment in improvement of wastewater collection system) and 0 was used to represented "no" response (i.e. no investment for ecosystem restoration or wastewater collection system improvement). In addition, ASC is very important interpretation of the respondents' preferences [12]. Dummy coding is also applied for ASC, 1 was coded if the respondents chose the current situation and 0 in case of choosing the improvement service (alternative A or B) [13] [14].

The utility associated with each alternative $j$, as evaluated by each individual $i$ in choice situation $k$, is represented in a discrete choice model by a utility ex- 
pression of the general form [15]:

$$
U_{i j k}=\beta_{0}+\beta_{1} X_{1 j k}+\beta_{2} X_{2 j k}+\beta_{3} X_{3 j k}+\beta_{4} X_{4 j k}
$$

where $\beta_{0}$ is the alternative specific constant (ASC) is the parameter for a particular alternative that is used to represent the role of unobserved sources of utility [15] and $X_{i j k}$ are the vector of attributes $\left(\beta_{1}\right.$ to $\left.\beta_{4}\right)$ that can influence respondents' utility.

In this study, the specific utility equations can be expressed as following:

$$
\begin{aligned}
& U(A)=\mathrm{ASC}+\beta_{1} \text { Quantity }+\beta_{2} \text { Ecores }+\beta_{3} \text { Wwimp }+\beta_{4} \text { fee } \\
& U(B)=\mathrm{ASC}+\beta_{1} \text { Quantity }+\beta_{2} \text { Ecores }+\beta_{3} \text { Wwimp }+\beta_{4} \text { fee } \\
& U(C)=\mathrm{ASC}+\beta_{1} \text { Quantity }+\beta_{2} \text { Ecores }+\beta_{3} \text { Wwimp }+\beta_{4} \text { fee }
\end{aligned}
$$

where:

$A$ and $B$-change alternatives;

$C$-status quo alternative;

$B_{1}$ to $\beta_{4}$-estimated coefficients.

Attributes:

Quantity-Quantity of treated wastewater;

Ecores-Ecosystem restoration;

Wwimp-Wastewater collection system improvement.

The status quo option was treated as the constant-only model for each attributes. Therefore, the differences in choice probabilities between the status quo and a specific option with different attribute levels were expressed in the estimated model parameters. All parameters used in this model are generic [16].

In this choice experiment, the ASC was included in the two alternatives that represented the percentage of respondents to participate in the wastewater treatment program. When the coefficient of ASC is negative and significant, it indicates a higher propensity to choose to maintain the current situation of water environmental quality when all else are constant. In other words, this implies that respondents systematically prefer the status quo option over the change options [14] [17].

Selecting the distributions of the random parameters is very important stage because distributions are important to reveal the real behavioral profile. For this study, all the attributes were estimated as normally distributed random parameters [15] [18] [19].

In addition, the fee variable is fixed and not randomly distributed for two reasons: 1) to avoid the difficulty of having the distribution of WTP for an attribute being the ratio of two distributions, 2) to restrict the fee variable to be non-positive for all individuals [18] [20].

\subsection{Conditional Logit and Random Parameter Logit Models}

In this study, HM tests were used to test the IIA assumption. The p-values for the tests is smaller than 0.05 . Hence the null hypothesis (violation of the IIA assumption does not occur) is rejected at 5 percent level of significance. Therefore, 
the CLM may not be the appropriate specification for the estimation.

To address the violation of the IIA, the random parameter logit (RPL) model was applied. RPL is a less restrictive model than the MNL in that it does not require the IIA property and allows for heterogeneity in preferences [21]. RPL models were estimated by using the LIMDEP 8.0 NLOGIT 3.0.

The estimated coefficients, standard errors and p-values of CL and RPL models are presented in Table 4. According to McFadden [22], values of 0.2 to 0.4 for Pseudo $\mathrm{R}^{2}$ represent an extremely excellent model fit in CLM and equivalent to 0.7 to 0.9 for linear function in OLS regression. The value of Pseudo $\mathrm{R}^{2}$ of this model is 0.34 ; therefore it is considered a very good model fit.

The ASC was positive and significant which indicated that the respondents systematically preferred the change options over the status quo. The value of 0.922 of the coefficient and statistically significant at 1 percent level on ecosystem restoration attribute showed that respondents are more likely to choose the change option if it provides more of the environmental improvements by restoring ecosystem. This is because most of respondents in the research sites are in their middle age and want to recall their childhood memories with many recreational activities such as swimming, fishing, and boating. Hence, they want the water quality in the rivers can be treated so that it will return to the same condition as before.

Local residents also prefer those wastewater treatment programs which can improve the wastewater collection system. The reason for this selection is that the wastewater collection systems in all communes of the study sites are very narrow and some parts of these systems have not been concreted. This results to the congestion of wastewater flow. Consequently, it causes the foul odor and air pollution. Based on the survey data, the respondents who live near the common wastewater collection system had headache higher about $15 \%$ than the others.

Table 4. Results from the conditional logit and random parameter logit models.

\begin{tabular}{ccccc}
\hline \multirow{2}{*}{ Attributes } & \multicolumn{3}{c}{ CL } & \multicolumn{2}{c}{ RPL } \\
\cline { 2 - 5 } & Coefficients & Standard error & Coefficients & Standard error \\
\hline ASC & $1.107^{* * *}$ & 0.230 & $1.316^{* * *}$ & 0.276 \\
Quantity $\left(\beta_{1}\right)$ & $0.964^{* * *}$ & 0.245 & $1.120^{* * *}$ & 0.293 \\
Ecores $\left(\beta_{2}\right)$ & $0.922^{* * *}$ & 0.823 & $1.017^{* * *}$ & 0.099 \\
Wwimp $\left(\beta_{3}\right)$ & $0.695^{* * *}$ & 0.814 & $0.837^{* * *}$ & 0.110 \\
Fee $\left(\beta_{4}\right)$ & $-0.258^{* * *}$ & 0.103 & $-0.296^{* * *}$ & 0.002 \\
& & Summary of statistics & & \\
No. of obs. & 2136 & & 2136 & \\
Pseudo- $R^{2}$ & 0.340 & & 0.342 & \\
LL-ratio test & 1597.728 & & 8.18 & \\
\hline
\end{tabular}

Note: No.of obs.: number of observation. ${ }^{* *}$ Significant at $1 \%,{ }^{*}$ Significant at $5 \%$, and ${ }^{*}$ Significant at $10 \%$. 
The negative coefficient for the environmental fee reflects the negative relationship between the environmental fee and utility of the wastewater treatment program, as expected. This means that increase in the environmental fee declines the combined utility level provided by the change alternatives.

\subsection{Estimation of Willingness to Pay}

The willingness to pay of the respondents for changes in each attribute level for the wastewater treatment program was estimated as implicit price (IP) estimates. The marginal value of a change for each attribute was calculated by dividing the $\beta$ coefficient of the attributes (Quantity, Ecores, and Wwimp) by the $\beta$ coefficient of the fee parameter and multiplied by -1 .

$$
\mathrm{IP}=-1\left(\frac{\beta_{\text {attribute }}}{\beta_{\text {money }}}\right)
$$

The mean monthly respondents' willingness-to-apy for each attribute from the different location sub-samples were described in Table 5.

In general, average households' willingness-to-pay was VND37,900 monthly additional environmental fee to ensure that wastewater is treated before it is released into the rivers in Hanoi City. They were also willing to pay VND34,390 in order to restore the ecosystem and VND28,320 to make sure that the wastewater collection system is improved. This means that, on average respondents placed the greatest concern about and willingness to pay more for the presence of the quantity of treated wastewater compared to other attributes.

To sum up, the willingness-to-pay for mean household is VND100,610 (or equivalent US $\$ 4.42 /$ month) as monthly additional environmental fee for wastewater treatment program in order to treat wastewater before discharge into the rivers in Hanoi City. The implicit prices of ecosystem restoration and wastewater collection system improvement attributes were positive and significant at $1 \%$ level implying that the respondents have positive WTP for the improvement in water quality in the research sites.

According to Lancsar and Savage [23] for the calculating WTP, when the attributes are linearly specified, the WTP for the entire good for changes in levels of all attributes are given by:

$$
\mathrm{WTP}=\sum_{j=1}^{J} \frac{\beta_{j}}{-\beta_{p}}\left(\Delta X_{j}\right)
$$

Table 5. The mean monthly households WTP for wastewater treatment.

\begin{tabular}{ccccc}
\hline & & Quantity $\left(\mathrm{m}^{3}\right)$ & Ecores & Wwimp \\
\hline \multirow{3}{*}{ Pooled } & CLM & $37.42^{* * *}$ & $35.78^{* * *}$ & $26.99^{* * *}$ \\
& & $(47.31-27.53)$ & $(32.42-39.14)$ & $(23.70-30.28)$ \\
& & $37.90^{* * *}$ & $34.39^{* * *}$ & $28.32^{* * *}$ \\
& RPL & $(27.77-48.03)$ & $(31.10-37.68)$ & $(24.89-31.75)$ \\
\hline
\end{tabular}

Notes: IPs calculated from the CL and RPL models, Significance levels indicated by: ${ }^{\star} 0.1,{ }^{* *} 0.05,{ }^{* * *} 0.01$ and $95 \% \mathrm{CI}$ in brackets. 
In order to obtain an average respondents' WTP under different scenarios with multiple changes in attributes and respective 95\% confidence intervals using Equation (4), Wald Procedure (Delta Method) was used in this study for analysis. The calculated implicit prices were reported only for significant coefficients are shown in Table 5 .

The utility of increase in quantity of treated wastewater has positive value, and similar low valuations also were reported in other studies [14] [19]. As can be seen in Table 6, it is visible that respondents give more preference to $90 \%$ of quantity of treated wastewater option, emphasizing higher quantity of treated wastewater scenarios. Hence, respondents have a positive marginal willingness to pay for the changes in volume of treated wastewater options moving away from the "status quo" situation. Based on the implicit prices calculated to monthly payments per household was also calculated.

Welfare impact of a service improvement on an average respondents' WTP under different scenarios with multiple changes in attributes can be measured by the compensating surplus (CS) welfare [19] [24] [25] [26]. This can be calculated as shown in Equation (5).

$$
\mathrm{CS}=-\frac{1}{\beta_{\text {monetary attribute }}}\left[\ln \sum_{n} \exp \left(V_{0 n}\right)-\ln \sum_{n} \exp \left(V_{1 n}\right)\right]
$$

where:

$V_{0 n}$ is the initial indirect utility functions;

$V_{1 n}$ is the changed indirect utility functions;

$\beta_{\text {monetaty attribute }}$ is the marginal utility of income.

Implicit prices reported in the tables of the preceding section cannot provide the estimation of compensating surplus (CS) for the hypothetical quantity of treated wastewater scenarios. For the purpose of calculating households compensating surplus for different quantity of treated wastewater options over the current situation, three possible volumes of treated wastewater scenarios were established.

- Scenario 1: Quantity of treated wastewater is $90 \%$; there is no ecosystem restoration and there is wastewater collection improvement.

- Scenario 2: Quantity of treated wastewater is $90 \%$; there is ecosystem restoration and there is wastewater collection improvement.

- Scenario 3: Quantity of treated wastewater is $90 \%$; there is ecosystem restoration and there is no wastewater collection improvement.

The CS for this study was computed from the choice model parameters of RPL and Equation (5) for the different scenarios as represented in Table 7.

Compensating surplus can be calculated by summation of the relevant marginal willingness to pay values [27] [28]. In addition, only the coefficients of the significant attributes were used to calculate the mean WTP. As can be seen in Table 6, as the policy options change toward improved environmental situation, the household's WTP will increase. In addition, since the respondents preferred one option to another one, they will give a higher willingness to pay for that option. 
Table 6. Implicit prices (IPs) for wastewater treatment optioned attributes (thousands VND/month/household).

\begin{tabular}{ccc}
\hline Attributes & Coefficient & Confidence interval (C.I) \\
\hline Quan4 & $14.84^{\star * *}$ & $11.00-18.68$ \\
Ecores & $33.65^{\star * *}$ & $30.44-36.86$ \\
Wwimp & $27.76^{\star * *}$ & $24.36-31.16$ \\
\hline
\end{tabular}

Notes: Quan4: Quantity of treated wastewater at level 4 (90\% of total discharged wastewater is treated). IPs calculated from the CL and RPL models, significance levels indicated by: ${ }^{\star} 0.1,{ }^{\star *} 0.05,{ }^{* *} 0.01$ and $95 \%$ C.I.

Table 7. Compensating surplus for three possible scenarios.

\begin{tabular}{ccc}
\hline Policy scenarios & Mean & Confidence interval (95\%) \\
\hline Scenario 1 & 42.60 & $35.36-49.84$ \\
Scenario 2 & 48.49 & $41.44-55.54$ \\
Scenario 3 & 76.25 & $65.80-86.70$ \\
\hline
\end{tabular}

Note: CS values are in thousands VND/household/month.

Scenario 1 is based on the highest level of quantity of treated wastewater (90\%) and improvement of wastewater collection system in relation to the status quo. The average WTP for this proposed scenario is VND42,600 for the pooled data. For Scenario 2, since the ecosystem restoration attribute is replaced by the wastewater collection system, the mean WTP goes up to VND48,490. The last scenario showed the mean WTP increasing to VND76,250 because of the presence of all attributes in the model.

\section{Conclusions and Policy Recommendations}

Wastewater is a major problem for handicraft villages in Vietnam, especially in Hanoi City, where craft villages are mostly concentrated. As the population grows, it increases the amount of wastewater generated from the population and production sector due to increasing demand for the product. This causes the severe environmental pollution, especially to the water environment. As a result, the state and local governments have planned to reduce environmental pollution and restore river basin ecosystems by building and renovating waste water collection and treatment systems. As long as the economic benefits are greater than the costs, it will increase the welfare of the people in improving the water environment. In order to assess the economic benefits, the willingness of people to pay for wastewater treatment must be estimated.

Based on the WTP level of $100,610 \mathrm{VND} /$ month (or equivalent US $\$ 4.42 /$ month) for an average household as shown in this study, those local governments in Hanoi City can collect the annual environmental fee about 1.21 million VND per household (or equivalent US\$53.07/year). There are 902 households who produce the agro-food product in the research sites. Therefore, the total annual environmental fee for wastewater treatment is estimated as 1089 million VND (equal to US $\$ 47,868 /$ year). This estimated budget accounted for $55.85 \%$ of total 
annual operation and maintenance costs only. In addition, the respondents also prefered to increase the quantity of treated wastewater to $90 \%$; hence, this also requires an increased investment for the existing wastewater collection systems.

It is very important to the policy makers because information about these matters is a critical element to develop the public wastewater treatment programs to address environmental pollution. Moreover, the results of this study would help the policy makers in both central and local government agencies in setting-up reasonable environmental fees to be allocated for water management in craft villages. In addition, based on the total potential budget of the household's willingness-to-pay, the government agency can socialize the total investment from many sources such as the residents in the craft villages, the investors and the local government budget. As a result, the wastewater treatment plants will be built and operated much faster.

\section{Acknowledgements}

The author would like to give the sincerely thank to Southeast Asia Regional Center for Graduate Study and Research Agriculture (SEARCA) provide me the financial support to conduct this research.

\section{Conflicts of Interest}

The authors declare no conflicts of interest regarding the publication of this paper.

\section{References}

[1] Edokpayi, J.N., Odiyo, J.O. and Durowoju, O.S. (2017) Impact of Wastewater on Surface Water Quality in Developing Countries: A Case Study of South Africa. Chapter 18, World's Largest Science, Technology \& Medicine, Open Access Book Publisher, 401-416. http://www.intechopen.com/books/water-quality https://doi.org/10.5772/66561

[2] Ndunda, E.N. and Mungatana, E.D. (2013) Evaluating the Welfare Effects of Improved Wastewater Treatment Using a Discrete Choice Experiment. Journal of Environmental Management, 123, 49-57. https://doi.org/10.1016/j.jenvman.2013.02.053

[3] WHO (2014) Investing in Water and Sanitation: Increasing Access, Reducing Inequalities. UN-Water Global Analysis and Assessment of Sanitation and Drinking-Water GLAAS 2014 Report.

[4] Lichtenberg, E. and Lessley, B. (1992) Water Quality, Cost-Sharing, and Technical Assistance: Perceptions of Maryland Farmers. Journal of Soil and Water Conservation, 47, 260-264.

[5] Forster, D.L., Bardos, C.P. and Southgate, D.D. (1987) Soil Erosion and Water Treatment Costs. Journal of Soil and Water Conservation, 42, 349-352.

[6] WHO (1997) Health and Environment in Sustainable Development: Five Years after the Earth Summit. Geneva.

[7] Agrwal, V.K. (2005) Environmental Laws in India: Challenges for Enforcement. Bulletin of the National Institute of Ecology, 15, 227-238. 
[8] Faure, M.G. (1995) Enforcement Issues for Environmental Legislation in Developing Countries. http://archive.unu.edu/hq/library/Collection/PDF_files/INTECH/INTECHwp19.pdf

[9] Helmer, R. and Hespanhol, I. (1997) Water Pollution Control-A Guide to the Use of Water Quality Management Principles. Published on Behalf of the United Nations Environment Programme, the Water Supply \& Sanitation Collaborative Council and the World Health Organization.

https://www.sswm.info/sites/default/files/reference_attachments/HELMER\%20and \%20HESPANHOL\%20Eds\%201997\%20Water\%20pollution\%20control\%20guide.p df

[10] Ambec, S. and Ehlers, L. (2014) Regulation via the Polluter-Pays Principle. http://onlinelibrary.wiley.com/doi/10.1111/ecoj.12184/epdf?r3_referer=wol\&trackin g_action=preview_click\&show_checkout $=1$ \&purchase_referrer=www.google.com.v $\underline{\text { n\&purchase_site_license=LICENSE_DENIED }}$

[11] VESDEC (2009) Large-Scale Research Program on Rivers' and Lakes' Water Quality in Hanoi.

[12] Morrison, M.D., Bennett, J.W., Blamey, R.K. and Louviere, J. (2002) Choice Modeling and Tests of Benefit Transfer. American Journal of Agricultural Economics, 84, 161-170. https://doi.org/10.1111/1467-8276.00250

[13] Louviere, J.J., Hensher, D.A. and Swait, J.D. (2000) Stated Choice Methods: Analysis and Application. Cambridge University Press, Cambridge. https://doi.org/10.1017/CBO9780511753831

[14] Birol, E. and Das, S. (2010) Estimating the Value of Improved Wastewater Treatment: The Case of River Ganga, India. Journal of Environmental Management, 91, 2163-2171. https://doi.org/10.1016/j.jenvman.2010.05.008

[15] Hensher, D., Rose, J.M. and Greene, W.H. (2005) Applied Choice Analysis: A Primer. Cambridge University Press, New York. https://doi.org/10.1017/CBO9780511610356

[16] Mazur, K. and Bennett, J. (2009) Location Differences in Communities' Preferences for Environmental Improvements in Selected NSW Catchments: A Choice Modelling Approach. 54th Annual Conference of the Australian Agricultural and Resource Economics Society, Cairns, 10-13 February 2009.

https://www.researchgate.net/publication/46472732_Location_differences_in_com munitie-

sa_preferences_for_environmental_improvements_in_selected_NSW_catchments_ A_Choice_Modelling_approach

[17] Hanley, N., Adamowicz, W. and Wright, R.E. (2005) Price Vector Effects in Choice Experiments: An Empirical Test. Resource and Energy Economics, 27, 227-234. https://doi.org/10.1016/j.reseneeco.2004.11.001

[18] Carlsson, F., Frykblom, P. and Liljenstolpe, C. (2003) Valuing Wetland Attributes: An Application of Choice Experiments. Ecological Economics, 47, 95-103. https://doi.org/10.1016/j.ecolecon.2002.09.003

[19] Ndunda, E.N. (2013) Wastewater Reuse in Urban and Peri-Urban Irrigation: An Economic Assessment of Improved Wastewater Treatment, Low-Risk Adaptation and Risk Awareness in Nairobi, Kenya. Published Doctoral Dissertation in Environmental Economics, University of Pretoria, Pretoria.

[20] Goett, A., Hudson, K. and Train, K. (2000) Customers' Choice among Retail Energy Suppliers: The Willingness-to-Pay for Service Attributes. Energy Journal, 21, 1-28. https://doi.org/10.5547/ISSN0195-6574-EJ-Vol21-No4-1 
[21] Revelt, D. and Train, K.T. (1997) Mixed Logit with Repeated Choices: Households' Choices of Appliance Efficiency Level. Review of Economics and Statistics, 80, 647-657. https://doi.org/10.1162/003465398557735

[22] Mcfadden, D. (1977) Quantitative Methods for Analyzing Travel Behavior of Individuals: Some Recent Developments. Cowles Foundation Discussion Paper No. 474, Cowles Foundation for Research in Economics, Yale University, New Haven.

[23] Lancsar, E. and Savage, E. (2004) Deriving Welfare Measures from Discrete Choice Experiments: Inconsistency between Current Methods and Random Utility and Welfare Theory. Health Economics, 13, 901-907. https://doi.org/10.1002/hec.870

[24] Bateman, I.J., Carson, R.T., Day, B., Hanemann, M., Hanley, N., Hett, T., Jones-Lee, M., Loomes, G., Mourato, S., Özdemiroglu, E., Pearce, D.W., Sugden, E. and Swanson, J. (2002) Economic Valuation with Stated Preference Techniques: A Manual. Edward Elgar, Cheltenham. https://doi.org/10.4337/9781781009727

[25] Bennett, J. and Adamowicz, W. (2001) Some Fundamentals of Environmental Choice Modeling. In: Bennett, J. and Blamey, R., Eds., The Choice Modeling Approach to Environmental Valuation, Edward Elgar, Cheltenham, 37-69.

[26] Hanemann, W.M. (1984) Welfare Evaluations in Contingent Valuation Experiments with Discrete Responses. American Journal of Agricultural Economics, 66, 332-341. https://doi.org/10.2307/1240800

[27] Champ, P.A., Boyle, K.J. and Brown, T.C. (2003) A Primer on Non-Market Valuation. The Economics of Non-Market Goods and Resources. Kluwer Academic Publishers, Boston. https://doi.org/10.1007/978-94-007-0826-6

[28] Goibov, M., Schimitz, P.M., Bauer, S. and Ahmed, M.N. (2012) Application of a Choice Experiment to Estimate Farmers Preferences for Different Land Use Options in Northern Tajikistan. Journal of Sustainable Development, 5, 1-16. https://doi.org/10.5539/jsd.v5n5p2 